\title{
Androgeny u kobiet pomenopauzalnych
}

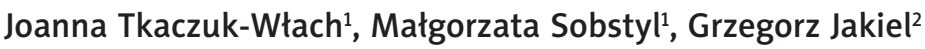 \\ ${ }^{1}$ Katedra i Klinika Ginekologii i Endokrynologii Ginekologicznej, Uniwersytet Medyczny w Lublinie \\ kierownik Katedry i Kliniki: prof. dr hab. n. med. Lechosław Putowski \\ 2) Klinika Położnictwa i Ginekologii, Centrum Medyczne Kształcenia Podyplomowego w Warszawie \\ kierownik Kliniki: prof. dr hab. n. med. Grzegorz Jakiel
}

Przegląd Menopauzalny 2013; 2: 180-184

\section{Streszczenie}

Właściwe stężenie androgenów jest warunkiem fizjologicznego przebiegu wielu ważnych procesów w organizmie kobiety - seksualnych, metabolicznych i psychicznych. Zarówno zbyt małe, jak i nadmiernie duże stężenia androgenów mogą powodować wiele negatywnych zmian w funkcjonowaniu organizmu kobiety. Niniejszy artykut stanowi przegląd wiedzy na temat fizjologicznej roli oraz zmian stężeń androgenów u kobiet w okresie około- i pomenopauzalnym.

Stowa kluczowe: kobiety, androgeny, menopauza, hiperandrogenizm, leczenie androgenami.

\section{Summary}

An appropriate level of androgens plays an important role in many physiological functions in women, such as sexual, metabolic and psychological ones. It is well established that extreme levels of circulating androgens, whether low or high, may lead to negative effects on women's health. This article is a review of knowledge of the physiological role and changes of androgen levels in peri- and postmenopausal women.

Key words: women, androgens, menopause, hyperandrogenism, androgen treatment.

\section{Zmiany okresu menopauzy i w okresie pomenopauzalnym}

Zmiany endokrynne zachodzące w okresie menopauzy i po niej dotyczą nie tylko stężeń i proporcji estrogenów, lecz także androgenów. U kobiet androgeny realizują swoje biologiczne działanie za pośrednictwem receptorów androgenowych i estrogenowych (po aromatyzacji do estrogenów).

Nie stwierdzono zmian w ekspresji i reaktywności receptora androgenowego $\mathrm{w}$ okresie pomenopauzalnym $[1,2]$.

Biosynteza androgenów w ustroju kobiety odbywa się na poziomie jajników, kory nadnerczy oraz obwodowej konwersji. Regulatorami wydzielania realizowanego przez jajnik i nadnercza są odpowiednio hormon luteinizujący (luteinizing hormone - LH) i hormon adrenokortykotropowy (adrenocorticotropic hormone - ACTH). Przez jajniki wydzielane jest $25 \%$ testosteronu, przez nadnercza kolejne $25 \%$. Pozostałe $50 \%$ powstaje na zasadzie obwodowej konwersji z androstendionu i dehydroepiandrosteronu (DHEA) w tkankach obwodowych, tj. skórze, wątrobie, mięśniach szkieletowych [2-4]. W okresie pomenopauzalnym większość, bo ok. 60\%, produkcji testosteronu realizowana jest na drodze pozajajnikowej. Wy- dzielanie dobowe testosteronu w okresie prokreacyjnym u kobiety kształtuje się na poziomie $250 \mu \mathrm{g} / \mathrm{ml}(0,2-0,3$ $\mathrm{mg})$, a po menopauzie średnio ok $180 \mu \mathrm{g} / \mathrm{ml}[3,4]$.

W 1974 r. opisano zmniejszenie stężeń testosteronu i androstendionu w surowicy kobiet pomenopauzalnych poddanych zabiegowi obustronnej owariektomii [5].

Obserwacja stężeń hormonów u kobiet po naturalnej menopauzie oraz u pacjentek po profilaktycznej owariektomii wykazała zmniejszenie stężenia testosteronu jedynie u kobiet po operacji. Oznacza to, że jajnik pełni swoją funkcję jako producent androgenów również po menopauzie $[5,6]$. Co więcej, na podstawie badań stwierdzono, że nawet wtedy gdy jajniki przestają produkować estrogeny - jajnikowa produkcja testosteronu utrzymuje się na względnie stałym poziomie [7].

Jajniki po menopauzie odpowiadają za syntezę $40 \%$ testosteronu i 20\% androstendionu [8]. Czynnikami mogącymi wpłynąć na zmniejszenie stężeń androgenów w późnym wieku pomenopauzalnym (po 65. roku życia) są najczęściej obustronna owariektomia, leczenie glikokortykosteroidami oraz mała masa ciała [9].

Przed menopauzą androstendion powstaje w połowie $\mathrm{w}$ jajniku i w połowie $\mathrm{w}$ nadnerczach. Produkowany jest z cholesterolu, a jego wydzielaniu towarzyszą zmiany zależne od fazy cyklu, z pikiem równoległym do 
owulacyjnego piku estradiolu [10]. Androstendion jest androgenem, który w okresie reprodukcyjnym produkowany jest $u$ kobiet $w$ stężeniach większych niż u mężczyzn i jedynie w 4\% związany jest z globuliną wiążącą hormony płciowe (sex hormone binding globulin - SHGB) $[2,11]$. Po menopauzie odsetek syntezy jajnikowej androstendionu spada do ok. 20\%, a za wytwarzanie tego hormonu odpowiadają już głównie nadnercza [2-4].

Z tego wynika ok. 50-procentowa redukcja stężenia androstendionu w surowicy kobiet. Spada tym samym produkcja testosteronu wynikająca z obwodowej konwersji androstendionu do testosteronu.

Znacząca większość produkcji DHEA i w zasadzie całości siarczanu dehydroepiandrosteronu (DHEAS) odbywa się w korze nadnerczy [10, 12].

Siarczan dehydroepiandrosteronu jest wydzielany prawie całkowicie przez nadnercza, nie ma różnic w jego wydzielaniu związanych z cyklem miesiączkowym oraz okresem przekwitania. Jego stężenie w surowicy wzrasta w okresie adrenarche, tj. ok. 7.-8. roku życia, ze szczytem wydzielania w 3. dekadzie życia. Potem następuje stopniowy spadek jego produkcji i ok. 70.-80. roku życia jego poziom wynosi już tylko ok. 20\% tego, który przypadał w szczytowym okresie wydzielania [10, 12]. Podczas gdy produkcja estrogenów zaczyna obniżać się znacząco 3-4 lata przed menopauzą [13], wytwarzanie androgenów nadnerczowych zmniejsza się stopniowo już od 30. roku życia [7], o ok. 2\% z każdym rokiem życia [13, 14].

Okazuje się, że stopień obniżenia poziomu DHEAS postępujący wraz z wiekiem jest różny w zależności od przynależności do grupy etnicznej. Przykładowo u Japonek odnotowano mniejszy spadek stężeń DHEAS występujący wraz z wiekiem niż wśród kobiet grupy kaukaskiej [13, 15].

Dehydroepiandrosteron jest produkowany przez nadnercza w ok. $50 \%$ i jajniki w ok. $20 \%$, z obwodowej konwersji z pregnenolonu powstaje ok. 30\% tego hormonu. Dzienna produkcja DHEA wynosi 6-8 mg. Jego stężenia zmieniają się wraz z wiekiem, podobnie jak w przypadku DHEAS [10].

Mniej niż 2\% testosteronu krąży jako wolny związek dostępny receptorowo. Reszta pozostaje związana z białkami: 60-65\% związane jest z SHGB, ok. 30-40\% z albuminami i ok. 5\% z transkotyną, czyli inaczej białkiem wiążącym kortykosteroidy (corticosteroid-binding globulin - CBG). Z dwoma ostatnimi białkami testosteron jest związany dość słabo, dlatego uważa się, że to SHGB stanowi główny nośnik tego steroidu [16].

W surowicy kobiet pomenopauzalnych wykazano znamiennie większe stężenia SHGB w porównaniu z tymi z okresu sprzed menopauzy. Zanotowano również w tej grupie wzrost testosteronu związanego, przy niezmienionych wartościach oznaczanego w surowicy testosteronu wolnego [2-4].

Podsumowując - „fizjologicznie” stężenie testosteronu wolnego $u$ kobiet $w$ okresie pomenopauzalnym w zasadzie nie ulega zmianie, a stężenie testosteronu całkowitego nawet się zwiększa. Towarzyszy temu zwiększenie stężenia SHGB. Zmniejszeniu ulega natomiast stężenie androstendionu, wraz z wiekiem dochodzi też do dalszego zmniejszenia stężeń DHEAS i DHEA.

\section{Niedobór androgenów u kobieł w okresie pomenopauzalnym}

Niedobór androgenów u kobiet może wynikać z procesów fizjologicznych, ale może być również elementem patologii czy działania czynników jatrogennych. Do przyczyn niedoboru androgenów wśród kobiet należą m.in. dysfunkcje osi podwzgórze-przysadka, chirurgiczna lub polekowa owariektomia oraz adrenalektomia, przedwczesne wygasanie czynności jajników, zespół Cushinga, radioterapia, chemioterapia czy nadczynność tarczycy [16]. Inne stany związane z niedoborem androgenów to: jadłowstręt psychiczny, reumatoidalne zapalenie stawów, toczeń rumieniowaty układowy, infekcja wirusem niedoboru odporności (human immunodeficiency virus - HIV) [10].

W celach klinicznych osiągnięto w 2002 r. konsensus dotyczący rozpoznawania niedoboru androgenów u kobiet, według którego uprawnia do jego rozpoznania obecność objawów klinicznych niedoboru oraz obniżony poziomu wolnego testosteronu, przy wykluczeniu niedomogi estrogennej [17].

Objawy kliniczne wymieniane jako składowe kobiecego zespołu niedoboru androgenów (female androgen insufficiency syndrome - FAIS) to utrata lub znacząco zmniejszone libido, zmniejszenie częstości występowania myśli i fantazji o treści seksualnej, zgłaszanie poczucia braku energii życiowej i nieuzasadnionego znużenia oraz pojawienie się obniżenia nastroju czy osłabienia pamięci. Do objawów klinicznych można zaliczyć: spadek masy kostnej i mięśniowej, wzrost masy tłuszczowej, zmniejszenie przekrwienia pochwy, zmniejszenie owłosienia łonowego oraz częstsze występowanie bólów głowy i epizodów depresji $[10,17,18]$.

$\mathrm{U}$ kobiet przed menopauzą na właściwe stężenie estrogenów wskazują m.in. regularne cykle miesięczne (co 21-35 dni) lub brak takich objawów, jak suchość pochwy czy uderzenia gorąca [10]. Tymczasem rozpoznanie niedoboru androgenów u kobiet pomenopauzalnych powinno się ustalać po próbie leczenia estrogenami, jeśli mimo takiego leczenia objawy nie ustępują lub wręcz nasilają się [11, 19]. Uważa się w tym kontekście, że optymalną drogą podawania estrogenów w terapii zastępczej jest droga parenteralna, w celu uniknięcia zwiększenia stężenia SHGB towarzyszącego podawaniu estrogenów drogą doustną [17].

Przyjmuje się, że stężenie testosteronu wolnego określa się jako małe, gdy wynosi lub jest poniżej poziomu odpowiadającego 25. percentylowi zakresu normy dla kobiet w wieku 20-40 lat [10]. Takie normy częściej 
przyjmowane są w stosunku do kobiet w młodszym wieku, natomiast dla kobiet starszych - po menopauzie - brak w literaturze jednoznacznych kwalifikacji klinicznych opartych na stężeniach wolnego testosteronu.

Do objawów ubocznych zgłaszanych mogących wystąpić w czasie podawania należą: trądzik, hirsutyzm oraz istotne klinicznie zmniejszenie stężenia cholesterolu frakcji lipoprotein o dużej gęstości (high density lipoprotein - HDL) [18]. Mogą również pojawić się arterogenne zmiany profilu lipidowego, przyrost masy ciała, zaburzenia czynności wątroby (zwłaszcza przy podawaniu doustnym), nieoczekiwane pobudzenie seksualne. $\mathrm{Na}$ temat potencjalnego wzrostu ryzyka raka piersi opinie są różne. W opublikowanym badaniu Nurses Health Study wykazano wzrost ryzyka raka piersi u kobiet po menopauzie stosujących terapię estrogenową łączoną z preparatami testosteronu w porównaniu z kobietami stosującymi same estrogeny lub estrogeny z gestagenami [20]. Podobnie w badaniu WHI (Women's Health Initiative) badacze ustalili dodatnią, choć nieistotną statystycznie, korelację między stosowaniem estrogenów i testosteronu a rakiem piersi [21]. Istnieją jednak doniesienia, w których autorzy bardzo jednoznacznie wypowiadają się o bezpieczeństwie terapii androgenami i podkreślają brak związku takiej terapii z ryzykiem rozwoju raka piersi i raka endometrium [20, 22].

Bezwzględne przeciwwskazania do leczenia androgenami stanowią: rak piersi, trzonu macicy i wątroby oraz choroby serca i krążenia [2].

Uważa się, że istnieje grupa kobiet pomenopauzalnych, u których terapia zastępcza w postaci samych estrogenów czy estrogenów z gestagenami nie przyniesie spodziewanych efektów poprawy jakości życia i w sytuacji braku efektu terapeutycznego powinien być dodawany androgen. Jest to jednak wciąż terapia drugiego rzutu.

Dostępne preparaty testosteronu występują w postaci doustnej, iniekcji podskórnych i domięśniowych oraz do aplikacji na skórę. W Polsce większość dostępnych preparatów testosteronu nie jest zarejestrowana do użytku dla kobiet. Z dostępnych na rynku należy wymienić preparaty - Biosteron (prasteron), który dostępny jest w dawkach 5, 10 i 25 mg z dopuszczalną maksymalną zalecaną dawką doustną dla kobiet wynoszącą $25 \mathrm{mg}$. Występuje jeszcze w postaci wstrzyknięć domięśniowych jako enantan prasteronu (200 mg) w połączeniu z walerianianem estradiolu (4 mg) i zakwalifikowany jest do leczenia objawów wypadowych u kobiet około- i pomenopauzalnych, u których występują niedobory estrogenów.

W 2006 r. Komisja Europejska przyznała pozwolenie na dopuszczenie do obrotu na terenie Unii Europejskiej plastrów z 300 mg testosteronu uwalnianymi w ciągu doby. Lek zakwalifikowano do leczenia objawów zaburzeń seksualnych $u$ kobiet po usunięciu macicy i obu jajników, leczonych preparatami estrogenowymi.

Opracowanie schematów i bezpiecznych dawek androgenów stosowanych w ramach suplementacji tych steroidów w przypadku ich niedoboru, przy wymienionych wyżej objawach, jest obecnie głównym nurtem badań klinicznych. Z opublikowanego w 2006 r. przeglądu badań z randomizacją w bazie Cochrane nie wynika jednoznaczna opinia dotycząca bezpieczeństwa stosowania u kobiet testosteronu. Określono jednak, że u kobiet stosujących hormonalną terapię zastępczą po dodaniu preparatów testosteronu uzyskano poprawę funkcji seksualnych (poprawa libido, wzrost aktywności seksualnej) w porównaniu z kobietami stosującymi samą tylko terapię zastępczą [19].

Inne doniesienia również potwierdzają korzystny wpływ na funkcje seksualne kobiet (wzrost pożądania, aktywności i satysfakcji seksualnej zarówno po menopauzie naturalnej, jak i chirurgicznej) stosujących jako uzupełnienie terapii estrogenowej preparatów testosteronu w formie plastrów [23-25].

Jak podkreśla wielu autorów, terapia testosteronem po menopauzie ukierunkowana na leczenie zaburzeń natury seksualnej powinna obejmować jednoczesne próby szerszego działania, w tym np. polepszenie relacji w związku czy leczenie zaburzeń seksualnych partnera. Jej istotnym elementem jest świadoma zgoda pacjentki ze względu na możliwe skutki uboczne terapii [25].

Z opublikowanych badań większość nie trwała dłużej niż 6 miesięcy i dlatego zaleca się kontrolę leczonej pacjentki właśnie po pół roku terapii i nieprzedłużanie jej na okres dłuższy niż rok [11, 22].

Kobiety leczone hormonalną terapią zastępczą z dodatkiem testosteronu powinny być $w$ trakcie leczenia monitorowane w sposób następujący: regularne badanie piersi i mammografia, badanie ginekologiczne $z$ badaniem ultrasonograficznym narządu rodnego, w przypadku niewyjaśnionych krwawień - biopsja endometrium. Badanie kliniczne powinno obejmować m.in. skórę (trądzik, łysienie androgenowe) i poszukiwanie objawów hirsutyzmu lub wirylizacji, które mogą rozwijać się dość stopniowo i w szerokim zakresie czasu - nawet powyżej roku od początku terapii. Wykonanie lipidogramu, oznaczenie stężenia glukozy lub wykonanie testu obciążenia glukozą zależą od indywidualnych wskazań [10].

\section{Hiperandrogenizm w okresie pomenopauzalnym}

Innym problemem jest nadmiar androgenów, który nie jest rzadkim problemem w wieku prokreacyjnym. Najczęściej w tym okresie życia kobiet źródłem hiperandrogenizmu są jajniki, a zespół policystycznych jajników (polycystic ovary syndrome - PCOS) stanowi najczęściej spotykaną endokrynopatię z tym związaną. W większości przypadków źródłem hiperandrogenizmu w okresie pomenopuazalnym pozostają jajniki. W tym jednak okresie budzi on często niepokój onkologiczny - zwłaszcza przy szybko narastających objawach androgenizacji, co wynika z podejrzenia 
wirylizującego guza jajnika. Spośród innych możliwych przyczyn hiperandrogenizmu należy wymienić przyczyny nadnerczowe (wrodzony i pourodzeniowy przerost nadnerczy, choroba i zespół Cushinga, guzy), czynnościowy hiperandrogenizm (functional adrenal hyperandrogenism - FAH) czy stosowanie leków o działaniu androgennym [26].

Zespół policystycznych jajników to choroba przewlekła, dotyczy praktycznie całego życia kobiety. Stężenie androgenów u kobiet z wywiadem obciążonym PCOS jest większe $w$ każdym wieku w porównaniu z tym obserwowanym $u$ kobiet $w$ analogicznym wieku, ale bez PCOS [27]. Często u kobiet z PCOS pod koniec wieku reprodukcyjnego obserwuje się powrót regularnych miesiączek, co wiąże się ze zmniejszeniem stężenia testosteronu - jednak wciąż pozostaje ono stosunkowo duże w porównaniu z występującym u kobiet zdrowych. Stąd zwiększone w tej grupie ryzyko rozwoju takich chorób, jak: choroby sercowo-naczyniowe, cukrzyca czy rak trzonu macicy [27]. Zwiększone stężenie androgenów zarówno w okresie przed-, jak i pomenopauzalnym uważa się za czynnik ryzyka rozwoju raka piersi [28, 29]. Trudno znaleźć dane na temat porównania stężenia androgenów u kobiet pomenopauzalnych otyłych z PCOS przed menopauzą oraz otyłych, ale bez wywiadu obciążonego występowaniem PCOS przed menopauzą.

Blisko 5-letnia obserwacja grupy kobiet pomenopauzalnych w kierunku potencjalnych czynników rozwoju nadciśnienia wykazała, że większe stężenie testosteronu - zarówno całkowitego, jak i wolnego - oraz stężenie DHEAS korelowały pozytywnie z ryzykiem rozwoju nadciśnienia u kobiety zdrowej przed badaniem [30]. W opublikowanych ostatnio wynikach greckiego badania prowadzonego wśród kobiet menopauzalnych większe stężenie testosteronu oraz indeksu wolnego testosteronu korelowały z objawami miażdżycy u uprzednio zdrowych kobiet. Były to czynniki ryzyka niezależne od innych, np. insulinooporność. W tym badaniu nie znaleziono związku między rozwojem miażdżycy i stężeniem DHEAS w surowicy [31].

Czynne hormonalnie guzy jajnika występujące u kobiet $w$ okresie pomenopauzalnym to: ziarniszczaki, otoczkowiaki, androblastoma, guz z komórek wnękowych, guz zrębu ciałka żółtego (luteoma), guz z komórek produkujących steroidy (steroid cell tumor) [26, 32].

Wyniki badań dodatkowych, m.in. testosteronu, najczęściej szybko potwierdzają duże jego stężenia. Tymczasem badania obrazowe - ultrasonografia jajników, tomografia komputerowa i rezonans magnetyczny miednicy mniejszej - często nie przynoszą jednoznacznej odpowiedzi ze względu na często bardzo małe rozmiary tych zmian.

Dlatego u kobiet w okresie postmenopauzy - w przypadku obecności objawów hiperandrogenizacji (hirsutyzm, wirylizacja), biochemicznych wykładników wskazujących na jajnikowe pochodzenie nadmiaru androgenów i jednoczesnym braku zmian w badaniach obrazowych jajników i nadnerczy - polecane jest rozważenie wykonania obustronnej owariektomii. Takie postępowanie skraca drogę do właściwej diagnozy i podjęcia leczenia [33].

Nienowotworową chorobą jajnikową skutkującą nadmiarem androgenów u kobiet pomenopazalnych może być hipertekoza jajnikowa [34]. Dotyczy ona najczęściej obu jajników, charakteryzuje się hiperplazją zrębu z rozsianymi zluteinizowanymi komórkami tekalnymi. Uważa się, że objawy hiperandorgenizacji wynikają z nieprawidłowej steroidogennezy jajnikowej zachodzącej pod kontrolą gonadotropin. Towarzyszy temu często nasilona hiperinsulinemia i insulinooporność. Hiperandrogenizm może być znacznie nasilony i dlatego hipertekoza wymaga, zwłaszcza w okresie postmenopauzalnym, różnicowania z guzem złośliwym jajnika [34]. W opublikowanych ostatnio badaniach okazało się, że przy bardzo podobnych klinicznej manifestacji objawów androgenizacji u kobiet pomenopauzalnych z potwierdzonym guzem jajnika stwierdzano większe stężenia testosteronu i mniejsze folikulotropiny i $\mathrm{LH}$ w porównaniu z oznaczonymi w pozostałych badanych przypadkach przyczyn hiperandrogenizmu [26].

Podsumowując - można zauważyć, że ekstremalne stężenia androgenów - zarówno zbyt duże, jak i małe mogą być przyczyną zaburzeń wpływających znacząco na jakość życia kobiety po menopauzie. Zwiększone stężenie endogennego testosteronu wiąże się z nieprawidłowym profilem lipidowym, podwyższonym ryzykiem rozwoju raka piersi czy endometrium oraz rozwojem insulinooporności. Tymczasem niedobór testosteronu może prowadzić do zaburzeń seksualnych (obniżone libido, spadek aktywności seksualnej), spadku sił witalnych czy obniżenia nastroju [16].

W praktyce klinicznej należy pamiętać o potrzebie wdrożenia diagnostyki w kierunku określenia stężenia androgenów u kobiet w okresie okołomenopauzalnym - szczególnie w sytuacjach szybko narastających objawów wirylizacji, opornych na leczenie estrogenami objawów klimakterium czy zaburzeń libido.

\section{Piśmiennictwo}

1. Jakiel G, Baran A. Androgen deficiency in women. Pol J Endocrinol 2005; 6: 1016-20.

2. Skałba P, Dabkowska-Huć A. Androgeny w okresie około- i pomenopauzalnym. Prz Menopauz 2006; 3: 132-7.

3. Longcope C. Adrenal and gonadal androgen secretion in normal females. Clin Endocrinol Metab 1986; 15: 213-28.

4. Burger HG. Androgen production in women. Fertil Steril 2002; 77: 3-5.

5. Judd HL, Lucas WE, Yen SS. Effect of oophorectomy on circulating testosterone and androstenedione levels in patients with endometrial cancer. Am J Obstet Gynecol 1974; 118: 793-8.

6. Korse CM, Bonfrer JM, van Beurden M, et al. Estradiol and testosterone levels are lower after oophorectomy than after natural menopause. Tumor Biol 2009; 30: 37-42.

7. Burger HG, Dudley EC, Cui J, et al. A prospective longitudinal study of serum testosterone, dehydroepiandrosterone sulfate, and sex hormonebinding globulin levels through the menopause transition. J Clin Endocrinol Metab 2000; 85: 2832-8. 
8. Adashi EY. The climacteric ovary as a functional gonadotropin-driven androgen-producing gland. Fertil Steril 1994; 62: 20-7. [Erratum in Fertil Steril 1995; 63: 684].

9. Cappola AR, Ratcliffe SJ, Bhasin S, et al. Determinants of serum total and free testosterone levels in women over the age of 65 years. J Clin Endocrinol Metab 2007; 92: 509-16.

10. Rivera-Woll LM, Papalia M, Davis SR, Burger HG. Androgen insufficiency in women: diagnostic and therapeutic implications. Hum Reprod Update 2004; 10: 421-32.

11. Androgeny. W: Hormonalna terapia zastępcza. Skałba P (red.). Wydaw nictwo Lekarskie PZWL, Warszawa 2005; 158-67.

12. Arlt W. Dehydroepiandrosterone and ageing. Best Pract Res Clin Endo crinol Metab 2004; 18: 363-80.

13. Lasley BL, Santoro N, Randolf JF, et al. The relationship of circulatin dehydroepiandrosterone. J Clin Endocrinol Metab 2002; 87: 3760-7.

14. Vermeulen A. Dehydroepiandrosterone sulfate and aging. Ann NY Acad Sci 1995; 774: 121-7.

15. Crawford S, Santoro N, Laughlin GA, et al. Circulating dehydroepiandrosterone sulfate concentrations during the menopausal transition. J Clin Endocrinol Metab 2009; 94: 2945-51

16. Yasui T, Matusi S, Tani A, et al. Androgen in postmenopausal women. Med Invest 2012; 59: 12-27.

17. Bachmann G, Bancroft J, Braunstein G, et al. Female androgen insuffi ciency: the Princeton consensus statement on definition, classification, and assessment. Fertil Steril 2002; 77: 660-5.

18. Braunstein GD. Androgen insufficiency in women: summary of critical issues. Fertil Steril 2002; 77 (Suppl 4): S94-9.

19. Somboonporn W, Davis S, Seif MW, Bell R. Testosterone for peri- and postmenopausal women. Cochrane Database Syst Rev 2005; 4: CD004509.

20. Shufeld CL, Braunstein GD. Testosterone and the breast. Menopuase Int 2008; 14: 117-22.

21. Ness RB, Albano JD, McTierman A, et al. Infleunce of estrogen plus testosterone supplementation on breast cancer. Arch Intern Med 2009; 169: 41-6.

22. Panzer C, Guay A. Testosterone replacement therapy in naturally and surgically menopause women. J Sex Med 2009; 6: 8-18
23. Simon J, Brunstein G, Natchtigall L, et al. Testosterone patch increases sexual activity and desire in surgically menopausal women with hypoactive sexual desire disorder. J Clin Endocrinol Metab 2005; 90: 5226-33.

24. Braunstein GD, Sundwall DA, Katz M, et al. Safety and efficacy of testosterone patch for the treatment of hypoactive sexual desire disorder in surgically menopausal women. Arch Intern Med 2005; 165: 1582-9.

25. Nappi RE, Albani F, Santamaria V, et al. Menopause and sexual desire: the role of testosterone. Menopause Int 2010; 16: 162-8.

26. Sarfati J, Bachelot A, Coussieu C, et al. Impact of clinical, hormonal, radiological, and immunohistochemical studies on the diagnosis of postmenopausal hyperandrogenism. Eur J Endocrinol 2011; 165: 779-88.

27. Winters SJ, Talbott E, Guzick DS, et al. Serum testosterone levels decrease in middle age in women with the polycystic ovary syndrome. Fertil Steril 2000; 73: 724-9.

28. Schover LR. Androgen therapy for loss of desire in women: is the benefit worth the breast cancer risk? Fertil Steril 2008; 90: 129-40.

29. Kenemans P, van der Mooren MJ. Androgens and breast cancer risk. Gynecol Endocrinol 2012; 28: 46-9.

30. Wang L, Szklo M, Folsom AR, et al. Endogenous sex hormones, blood pressure change, and risk of hypertension in postmenopausal women: the Multi-Ethnic Study of Atherosclerosis. Atherosclerosis 2012; 224: 228-34.

31. Creatsa M, Armeni E, Stamatelopoulos K, et al. Circulating androgen levels are associated with subclinical atherosclerosis and arterial stiffness in healthy recently menopausal women. Metabolism 2012; 61: 193-201.

32. Honoré LH, Chari R, Mueller HD, et al. Postemnopausal hyperandrogenism of ovarian origin. A clinicopathological study of four cases. Gynecol Obstet Invest 1992; 34: 52-6.

33. Ashawesh K, Abdulqawi R, Redford D, Barton D. Postmenopausal hyperandrogenism of ovarian origin: diagnostic and therapeutic difficulties. Endocr J 2007; 54: 647.

34. Vaikkakara S, Al-Ozairi E, Lim E, Advani A, et al. The investigation and management of severe hyperandrogenism pre- and postmenopause non-tumor disease is strongly associated with metabolic syndrome and typically responds to insulin-sensitization with metformin. Gynecol Endocrinol 2008; 24: 87-92.

Prawidtowe odpowiedzi do Testowego programu edukacyjnego dotyczącego androgenów u kobiet w okresie pomenopauzalnym zamieszczonego w numerze 1/2013 Przeglądu Menopauzalnego:

1. b; 2. c; 3. d; 4. d; 5. c; 6. d; 7. a; 8. b; 9. c; 10. d; 11. d; 12. a; 13. d; 14. d. 